\title{
Respiratory changes related to prematurity in neonatal intensive care
}

\author{
Alterações respiratórias relacionadas à prematuridade em terapia intensiva neonatal
}

Francieli Cristina $\mathrm{Krey}^{1}$, Joseila Sonego Gomes ${ }^{2}$, Eliane Raquel Rieth Benetti ${ }^{3}$, Cibele Thomé da Cruz ${ }^{1}$, Mariléia Stübe $^{4}$, Eniva Miladi Fernnades Stumm²

Objective: to identify respiratory clinical changes in preterm newborns hospitalized in the Neonatal Intensive Care Unit. Methods: this is a documentary research with 145 medical records by an instrument with sociodemographic variables of preterm newborns and their mothers. Results: most of the newborn were male, $66.9 \%$ were born surgically, $64.8 \%$ were moderately premature, and the birth weights were between 1,500 and 2,500 grams. Among the respiratory changes, there were early respiratory dysfunction, hyaline membrane, and apnea. There was the prevalence of women in preterm labor (42.8\%), water breaking (32.4\%) and pre-eclampsia $(20.7 \%)$ among others were found to be related to obstetric factors related to prematurity. Conclusion: a high incidence of preterm births was observed, with significant respiratory changes.

Descriptors: Infant, Newborn; Infant, Premature; Intensive Care, Neonatal; Nursing.

Objetivo: identificar alterações clínicas respiratórias em recém-nascidos pré-termo internados em Unidade de Terapia Intensiva Neonatal. Métodos: pesquisa documental, com145 prontuários, por meio de instrumento com variáveis sociodemográficas de recém-nascidos pré-termo e respectivas mães. Resultados: a maioria dos nascidos era do sexo masculino, 66,9\%nascidos por via cirúrgica, 64,8\%com prematuridade moderada e peso de nascimento entre 1.500 e 2.500 gramas. Dentre as alterações respiratórias, destacaram-se disfunção respiratória precoce, membrana hialina e apneia. Em relação aos fatores obstétricos relacionados à prematuridade, constatou-se prevalência de mulheres em trabalho de parto prematuro $(42,8 \%)$, bolsa rota $(32,4 \%)$ e préeclâmpsia (20,7\%), além de outros. Conclusão: constatou-se incidência elevada de nascidos prematuros, com alterações respiratórias importantes.

Descritores: Recém-Nascido; Prematuro; Terapia Intensiva Neonatal; Enfermagem.

\footnotetext{
${ }^{1}$ Hospital de Caridade de Ijuí. Ijuí, RS, Brazil.

${ }^{2}$ Universidade Regional do Noroeste do Estado do Rio Grande do Sul. Ijuí, RS, Brazil.

${ }^{3}$ Hospital Universitário de Santa Maria. Santa Maria, RS, Brasil.

${ }^{4}$ Hospital Escola da Universidade Federal de Pelotas. Pelotas, RS, Brazil.

Corresponding author: Eniva Miladi Fernandes Stumm

Rua 20 de setembro, 902 Centro, CEP: 98700-000. Ijuí, RS, Brazil. E-mail: eniva@unijui.edu.br
} 


\section{Introduction}

There is a great concern in Brazil regarding maternal and child health, as in many parts of the world, due to the increase in births of preterm infants ${ }^{(1)}$. The importance of studies addressing prematurity is due to the increase in the incidence of neonatal morbidity and mortality, as well as the high costs of hospitalizations and sequels of multiple natures.

The proportion of preterm newborns has been stable in Brazil since 2000, presenting an average rate of $6.6 \%$. The development of Intensive Care Units for neonatal care increased the survival rate of these preterm infants ${ }^{(2)}$. However, even with the advancement of technology, the effects of prematurity, throughout life are little known. The understanding of the case/consequence relationship of premature birth over chronic diseases in later life is also limited ${ }^{(3)}$.

Preterm birth was defined(4) as the baby with less than 37 weeks of gestation. Prematurity is classified into three groups: borderline (35 to 36 weeks and six days of gestational age), moderate (30 to 34 weeks and six days of gestational age) and extreme (less than 30 weeks of gestational age) ${ }^{(4)}$.

Borderline prematurity has $65.0 \%$ of preterm infants born alive, whose birth weight is between 2,200 and 2,800 g. Neonatal mortality in this group is small, less than $1.0 \%$. At moderate prematurity, birth weight may range from 1,600 to $2,300 \mathrm{~g}$ and the main causes of death in this group are related to respiratory failure, especially to hyaline membrane disease and respiratory infections. In extreme prematurity, birth weight is less than $1,500 \mathrm{~g}$ and clinical intercurrences often appear and are more severe due to extreme immaturity ${ }^{(5)}$.

During the gestation, the physiological functions of the fetus are maintained by the mother through the placenta. At birth, the newborn needs to fulfill its physiological functions, but preterm infants are often incapable and are more likely to develop respiratory, neurological, cardiovascular, hematological, nutritional, immunological and ophthalmological changes ${ }^{(2)}$.

In this sense, the use of an early multidisciplinary approach is necessary to minimize or prevent sequels. The preventive measures adopted in the neonatal period involve all care for preterm infants and are not easily established since the pathophysiology is complex and multifactorial. Premature infants are more prone to future aggravations arising from the condition of prematurity, as a consequence of organ immaturity and low birth weight damage ${ }^{(6)}$.

Based on these considerations, this study aimed to identify respiratory clinical changes in preterm newborns admitted to the Neonatal Intensive Care Unit.

\section{Methods}

This is a documentary research, developed in the Neonatal Intensive Care Unit of a Hospital type IV, located in the Northwest region of the state of Rio Grande do Sul, Brazil. It is a macro-regional reference in neonatology, which integrates the State Central of bed regulation and it has eight beds of hospitalization registered through the Unified Health System.

Data on preterm newborns were collected in the medical records. The collection consisted of two stages. In the first stage, the medical records were identified with the help of the computer system and the records book of the Neonatal Intensive Care Unit. In the second stage, the data were collected in medical files in the Medical File System of the institution. The variables analyzed were: gender, gestational age at birth, weight, birth conditions, delivery route, maternal age and to identify the clinical changes presented by the newborns and to relate the pulmonary changes to the types of prematurity.

Records of preterm newborns hospitalized by the Unified Health System agreement, from January 2010 to December 2012 were included in the study. The option for 2010 to start collection was because the regulation of the beds of the Intensive Care Unit 
in this year started to be made by the bed center of the state of Rio Grande do Sul, Brazil. Medical records of preterm infants who died during admission were excluded. The collection was carried out in May 2013, on random days and times. An instrument developed by the researchers was used, after a bibliographical review on the subject, which includes sociodemographic variables of the preterm newborns and their mothers and clinical respiratory changes related to prematurity ${ }^{(1,5)}$.

The data collected were tabulated in Excel spreadsheets, and after they had been submitted to descriptive statistical analysis, with means and standard deviation for continuous variables, for discrete variables, they were dichotomized and presented with frequency, percentage, confidence interval (95.0\%), upper and lower limits. Data were presented in tables, summarized with the help of the Statistical Package program for the Social Sciences, version 17.0.

The study complied with the formal requirements contained in the national and international regulatory standards for research involving human beings.

\section{Results}

The results indicated that more than half of the preterm infants were male (53.8\%). At birth, $61.4 \%$ of them had a weight between 1,500 and 2,500 grams, with an average of 1916 grams, ranging from 545 grams (minimum) to 4,290 grams (maximum). It was found that $64.8 \%$ of the preterm newborns were born with gestational age between 30 and 34 weeks, that is, moderate prematurity. The mean gestational age in weeks was 33.25, ranging from 25 weeks (minimum) to 36 weeks (maximum). Regarding the birth route, the surgical route prevailed (66.9\%).

Table 1 shows the characteristics of preterm newborns in the research.
Table 1 - Characteristics of premature newborns

\begin{tabular}{lcc}
\hline Variables & n (\%) & $\begin{array}{c}\text { Confidence Interval (95\%) } \\
\text { Upper and Lower Limits }\end{array}$ \\
\hline Gender & $78(53.8)$ & $45,69-61.91$ \\
Male & $67(46.2)$ & $38,09-54.31$ \\
Female & & \\
Type of prematurity & $94(64.8)$ & $57,03-72.57$ \\
Moderate & $45(31.0)$ & $23,47-38.53$ \\
Borderline & $6(4.1)$ & $0,87-7.33$ \\
Extreme & & $15,88-29.52$ \\
Weight at birth (grams) & & $53,48-69.32$ \\
Less than 1500 & $33(22.7)$ & $9,95-21.85$ \\
1500|--- 2500 & $89(61.4)$ & \\
2500 or more & $23(15.9)$ & $59,24-74.56$ \\
Birth route & & $25,44-40.76$ \\
Surgical & $97(66.9)$ & \\
Vaginal & $48(33.1)$ &
\end{tabular}

Regarding the maternal age, $4.1 \%$ were younger than 15 years old, 41.4\% were between 15 and 25 years old, $31.8 \%$ were between 26 and 35 years old, $11.8 \%$ were older than 35 , and $11.0 \%$ did not have this information. Women with gestational age represented $15.9 \%$ of the cases, $4.1 \%$ with less than 15 years old and $11.8 \%$ with more than 35 years old. The mean and standard deviation of maternal age were $25.71 \pm 7.06$ years old; the lowest age was 14 years old, and the highest age was 44 years old.

In the delivery room, $76.6 \%$ of newborns required inhaled oxygen, $9.7 \%$ needed cardiorespiratory resuscitation, and $6.9 \%$ needed endotracheal intubation still in the delivery room. It is noteworthy that $43.4 \%$ of the hospitalizations of the preterm infants occurred in the State Regulation Center, that is, they were transferred from other municipalities in the region.

Table 2 shows the obstetric factors related to prematurity. Prevalence of women in preterm labor (42.8\%), water breaking (32.4\%) and pre-eclampsia $(20.7 \%)$ was found to be prevalent, among others. 
Most of the pregnant women presented more than one obstetric factor related to premature birth, elucidated in the table by the number of times that occurred.

Among the respiratory changes presented by preterm newborns, the early respiratory dysfunction (97.2\%), hyaline membrane $(56.0 \%)$ and apnea $(28.7 \%)$ are highlighted. Most of the preterm infants were hospitalized for some of the respiratory changes described below and progressed to another condition (s) after some time and throughout hospitalization, which justifies the occurrence of more than one event in patients in the records searched.

The respiratory changes related to the type of prematurity are described in Table 3 . The most incidents in this study were early respiratory dysfunction (97.2\%), hyaline membrane (38.6\%) and apnea (29.7\%). Regarding the type of prematurity, it is evident that all babies classified as preterm infants presented early respiratory depression and hyaline membrane, $83.3 \%$ bronchopulmonary dysplasia and $50.0 \%$ atelectasis. Pneumonia was less common (12.8\%) in moderate prematurity.
Table 2 - Obstetric factors related to prematurity in newborns

\begin{tabular}{lcc}
\hline $\begin{array}{l}\text { Reason for Premature } \\
\text { (n=145) }\end{array}$ & Birth (\%) & $\begin{array}{c}\text { Confidence Interval } \\
\text { (95\%) Upper and } \\
\text { Lower Limits }\end{array}$ \\
\hline Preterm labor & $62(42.8)$ & $34.75-50.85$ \\
Water breaking & $47(32.4)$ & $24.78-40.02$ \\
Pre-eclampsia & $30(20.7)$ & $14.11-27.29$ \\
Urinary infection & $27(18.6)$ & $12.27-24.93$ \\
Maternal sepsis & $22(15.2)$ & $9.36-21.04$ \\
Oligodrhmnium & $15(10.3)$ & $5.35-15.25$ \\
Gestational Hypertension & $14(9.7)$ & $4.88-14.52$ \\
Broken Placenta & $10(6.9)$ & $2.77-11.03$ \\
Twin pregnancy & $9(6.2)$ & $2.27-10.13$ \\
Pluriparity & $9(6.2)$ & $2.27-10.13$ \\
Smoking & $5(3.4)$ & $0.45-6.35$ \\
Intrauterine growth retardation & $4(2.8)$ & $0.11-5.49$ \\
Gestational diabetes & $4(2.8)$ & $0.11-5.49$ \\
Human immunodeficiency virus & $4(2.8)$ & $0.11-5.49$ \\
Fetal suffering & $3(2.1)$ & $0.00-4.43$ \\
Hellp Syndrome & $3(2.1)$ & $0.00-4.43$ \\
Drug user & $2(1.4)$ & $0.00-3.31$ \\
Alcohol consumption & $2(1.4)$ & $0.00-3.31$ \\
Other & $9(6.2)$ & $2.27-10.13$ \\
\hline & & \\
\hline
\end{tabular}

Table 3 - Respiratory changes related to prematurity

\begin{tabular}{|c|c|c|c|c|c|}
\hline \multirow[b]{2}{*}{ Respiratory changes } & \multicolumn{3}{|c|}{ Type of prematurity } & \multicolumn{2}{|r|}{ Confidence interval (95\%) } \\
\hline & $\begin{array}{c}\text { Extreme } \\
(n=6)\end{array}$ & $\begin{array}{c}\text { Borderline } \\
(n=45)\end{array}$ & $\begin{array}{c}\text { Moderate } \\
(n=94)\end{array}$ & $\begin{array}{c}\text { Total } \\
(n=145)\end{array}$ & Upper and lower limits \\
\hline Early respiratory dysfunction & $6(100)$ & $43(95.5)$ & $92(96.8)$ & $141(97.2)$ & $94.51-99.89$ \\
\hline Hyaline membrane & $6(100)$ & $6(13.3)$ & $44(46.8)$ & $56(38.6)$ & $30.68-46.52$ \\
\hline Apnea & $2(33.3)$ & $12(26.7)$ & $29(30.8)$ & $43(29.7)$ & $22.26-37.14$ \\
\hline Respiratory insufficiency & $2(33.3)$ & $5(11.1)$ & $19(20.2)$ & $26(17.9)$ & $11.66-24.14$ \\
\hline Newborn tachypnea & - & $11(24.4)$ & $13(13.8)$ & $24(16.6)$ & $10.54-22.66$ \\
\hline Pneumonia & $2(33.3)$ & $11(24.4)$ & $12(12.8)$ & $25(17.2)$ & $11.06-23.34$ \\
\hline Bronchopulmonary dysplasia & $5(83.3)$ & - & $8(8.5)$ & $13(9.0)$ & 4.34- 13.66 \\
\hline Atelectasis & $3(50)$ & $2(44.4)$ & $5(5.3)$ & $10(6.9)$ & $2.77-11.03$ \\
\hline Pulmonary artery stenosis & - & $1(2.2)$ & $6(6.4)$ & $7(4.8)$ & $1.32-8.28$ \\
\hline Pulmonary hypertension & - & $3(6.7)$ & $2(2.1)$ & $5(3.4)$ & $0.45-6.35$ \\
\hline Pulmonary hemorrhage & $2(33.3)$ & - & - & $2(1.4)$ & $0.00-3.31$ \\
\hline Pneumothorax & $2(33.3)$ & - & - & $2(1.4)$ & $0.00-3.31$ \\
\hline Other & - & $2(4.4)$ & $2(2.1)$ & $4(2.8)$ & $0.11-5.49$ \\
\hline
\end{tabular}




\section{Discussion}

Results of this study indicate that prematurity occurred in a higher percentage of newborn males. Regarding this variable, studies show that it is not influenced on the occurrence of preterm deliveries ${ }^{(7-8)}$. The increase in premature births is concentrated in newborns with gestational age between 35 and 36 weeks of gestation, both in surgical deliveries and in vaginal deliveries ${ }^{(1)}$. In this study, the preterm neonates prevailed moderately, ranging from 30 to 34 weeks and six days of gestation, because those hospitalized in a Neonatal Intensive Care Unit were investigated and the borderline preterm newborns presented better conditions at birth and do not require intensive care.

The average gestational age is similar when compared to another study ${ }^{(9)}$, also influenced by the prevalence of cesarean births with moderate and borderline preterm newborns ${ }^{(7-9)}$. The incidence of extreme prematurity was higher when compared to other studies with similar numbers of participants, and low weight was present in most of the study population $^{(8)}$. As important as gestational age, there is the weight of the newborn at birth. There was a prevalence of those born with 1,500 to 2,500 grams, mean weight of 1,916 grams, characterized as low birth weight.

The study points to a higher risk of death for newborns with a birth weight of 1,500 to 2,499 grams or less than 1,500 grams. Also, other variables were Apgar index lower than 7 in the $5^{\text {th }}$ minute of life, use of mechanical ventilation and birth with less than 32 weeks of gestational age ${ }^{(10)}$. Also, extreme prematurity and very low birth weight (less than 1,500 grams) accounted for $60.2 \%$ and $59.6 \%$ of neonatal deaths in a cohort study on neonatal mortality in Nascer Brazil study ${ }^{(11)}$.

The Brazilian Ministry of Health considers the individual characteristics and sociodemographic conditions of the pregnant woman as pregnancy markers and risk factors for preterm birth, such as age over 35 years old and under 15 years old ${ }^{(12)}$. This study did not show a higher prevalence of women, preterm newborns, in age groups at risk, different to the findings of other studies showing the extreme age groups, adolescents and women aged 35 years old and over, as determining factors for prematurity ${ }^{(13-14)}$. It should be emphasized that maternal age may contribute to preterm birth, but it should not be considered an isolated risk factor.

Regarding the type of delivery, other studies also showed a higher occurrence of preterm birth through the surgical delivery ${ }^{(1,7)}$. The increase in the rates of prematurity among newborns is in contrast to the advances in the survival of another group of newborns, those with low birth weight, due to improvements in neonatal care. It is also noted that medical interventions, such as a cesarean section, contribute to the increase in preterm birth. Also, there is evidence that the increase in the frequency of this type of delivery may be responsible for the increase in the prematurity rates, and they have interfered in the advances regarding the survival of low birth weight infants $^{(15)}$.

The newborns surveyed received emergency care in the delivery room. This care needs to ensure that the transition from intrauterine to extrauterine life succeeds. The body needs to make physiological adjustments immediately after birth, especially in those born prematurely. In this sense, the preterm newborn should receive specialized care in the delivery room, which consists of maintaining body temperature, establishing a patent airway and stimulating breathing ${ }^{(16)}$.

In general, preterm birth is associated with conditions of the inability of the uterus to retain the fetus due to interferences in the course of gestation. The epidemiological study points to several factors responsible for the prevalence of preterm births. More than $96.0 \%$ of the cases of low birth weight infants occur in developing countries, which shows 
that this situation is likely to occur in unfavorable socioeconomic conditions, in which pregnant women are more susceptible to inadequate food, infections and health problems ${ }^{(17)}$. In this study, higher percentages of women with preterm labor, followed by a water breaking pocket, preeclampsia, and urinary tract infection were found in the study analyzed, among the causes of preterm birth.

Premature infants presented an increased risk for different clinical changes, such as respiratory disorders, such as a hyaline membrane, severe respiratory failure, apnea, pneumothorax, interstitial emphysema, bronchopulmonary dysplasia and prolonged oxygen dependence. A cross-sectional study analyzed the main characteristics of newborns and diagnosed the complications of late preterm infants compared to full-term infants. Respiratory problems and hypoglycemia were more frequent in late preterm infants compared to full-term infants $(\mathrm{p}<0.001)^{(18)}$.

Hyaline Membrane Disease occurs in $44.0 \%$ of infants weighing between 500 and 1,500 grams, incidence inversely proportional to gestational age and birth weight. The incidence and severity of Hyaline Membrane Disease have decreased after birth steroid use in recent years and survival has increased significantly, especially after the introduction of exogenous surfactant, currently greater than $90.0 \%{ }^{(1)}$.

Respiratory distress may represent a benign condition, such as a delay in cardiorespiratory adaptation, but it may also be the first sign of a serious and potentially lethal infection, and recognition and early assessment are essential. Most of the neonatal respiratory diseases were shown in the first hours of life, soon after birth, in a non-specific way and, often, with overlapping signs and symptoms. Due to the structural and functional peculiarities related to the immaturity of the respiratory system, pulmonary diseases in the neonatal period are characteristically and clinically characterized by newborns.
Approximately $10.0 \%$ of all newborns require some assistance to start breathing after birth, and an approximate percentage of $1.0 \%$ of them need to undergo more extensive resuscitation efforts ${ }^{(1)}$. In this sense, the delivery room should maintain an organized team, qualified in resuscitation techniques and adequate and available equipment ${ }^{(1)}$. In prematurity, there is a higher incidence of early and transient respiratory discomfort, transitory tachypnea, due to a delay in the elimination of interalveolar fluid, which is self-limiting and persistent only during the first hours of life.

In moderate and extreme prematurity, early respiratory dysfunction has a sudden onset, usually newborns who require inhaled oxygen in the delivery room, evolve to respiratory failure leading to Hyaline Membrane Disease ${ }^{(19)}$. The quantitative and qualitative deficiency of alveolar surfactant is its main cause. The preterm newborn with a gestational age of fewer than 35 weeks is deficient in the total amount of pulmonary surfactant ${ }^{(19)}$. The study is in agreement with the bibliographic findings since it was verified that the totality of the preterm newborns and about half of the moderates presented such alteration, being little present in the borderline due to the pulmonary maturity of this group.

The biological vulnerability of preterm infants and low birth weight to risks arising from the therapeutic process in neonatal intensive care units is highlighted, considering the use of high complexity procedures and lengthy hospitalization.

Based on these considerations, the team that works at the Neonatal Intensive Care Unit aims at comprehensive care, which meets the needs of newborns, extended to their families. To do this, it is necessary for the professionals to be aware of the importance of the presence of the family and their participation in care, as well as the valuation of the multi-professional team, with a view to teamwork and concern for continuity of care after discharge, 
especially newborns at high $\operatorname{risk}^{(20)}$. It is also emphasized the importance of constant professional qualification focused on integral care, as well as actions to prevent premature birth.

This study is limited because the classification of preterm infants in the three groups showed significant differences in the numbers of hospitalizations and, therefore, do not allow the performance of statistical tests that can relate the classification of prematurity with respiratory changes.

\section{Conclusion}

The research allowed to identify that prematurity is related to several pulmonary clinical changes, and the most frequent were early respiratory dysfunction, hyaline membrane, and apnea. It should be noted that pulmonary hemorrhage and hemothorax occurred only in premature infants. Preterm labor, a water breaking, and women with pre-eclampsia are obstetric factors associated with preterm birth.

As professionals that integrate the health team, nurses should focus their actions to prevent the occurrence of premature birth and the birth of very low birth weight infants. To that end, the identification of maternal, fetal and neonatal changes are fundamental aspects that should integrate the planning of actions to prevent and improve the quality of nursing care for pregnant women in prenatal care, pre-delivery, delivery and puerperium and to newborns preterm infants throughout the neonatal period.

\section{Collaborations}

Krey FC and Gomes JS contributed to work design, analysis, data collection, data interpretation and article writing. Benetti ERR, Cruz CT, Stübe M and Stumm EMF contributed to the analysis, interpretation of data, article writing, critical review of content and final approval of the version to be published.

\section{References}

1. Granzotto JA, Fonseca SS, Lindemann FL. Fatores relacionados com a mortalidade neonatal em uma unidade de terapia intensiva neonatal na região sul do Brasil. Rev AMRIGS. 2012; 56(1):57-62.

2. Ministério da Saúde (BR). Cuidados com o recémnascido pré-termo. Atenção à saúde do recémnascido. Brasília: Ministério da Saúde; 2010.

3. Almeida TSO, Lins RP, Camelo AL, Mello, DCCL. Investigação sobre os Fatores de Risco da Prematuridade: uma Revisão Sistemática. R Bras Ci Saúde. 2013; 17(3):301-8.

4. Ramos JGL, Martins SHC, Valério EG, Muller ALL. Nascimento pré-termo. In: Freitas F, Martins SHC, Ramos JGL, Magalhães JA. Rotinas em obstetrícia. Porto Alegre: Artmed; 2011. p.69-80.

5. Gomella TL. Neonatologia - manejo, procedimentos, problemas no plantão, doenças e drogas. Paraná: Revinter; 2012.

6. Coelli AP, Nascimento LR, Mill JG, Molina MCB. Prematuridade como fator de risco para pressão arterial elevada em crianças: uma revisão sistemática. Cad Saúde Pública. 2011; 27(2):20718.

7. Silva RP, Caires BR,NogueiraDA, Moreira DS, Gradim CVC, Leite EPRC. Prematuridade: Características maternas e neonatais segundo dados do sistema de informações sobre nascidos vivos. Rev Enferm UFPE on line [Internet]. 2013[citado $2016 \mathrm{Abr}$ 13]; 7(5):1349-55. Disponível em: http://www. revista.ufpe.br/revistaenfermagem/index.php/ revista/article/viewFile/4363/pdf_2510

8. Silva RP, Caires BR, Nogueria DA, Moreira DS, Gradim CVC, Leite EPRC. Prematurity: maternal and neonatal characteristics according to datafrom the information system on live births. Rev Enferm UFPE on line [Internet]. 2013 [cited 2016 Apr 13]; 7(5):1349-55. Available from:http://www. revista.ufpe.br/revistaenfermagem/index.php/ revista/article/viewFile/4363/pdf_25

9. Bozzetto C, Grave MTQ, Périco E. Incidência de nascimentos prematuros em hospital de um município do Vale do Caí. Rev Destaques Acad. 2013; 5(3):103-10. 
10. Silva AAM, Leite AJM, Lamy ZC, Moreira MEL, Gurgel RQ, Cunha AJLA, et al. Morbidade neonatal near miss na pesquisa Nascer no Brasil. Cad Saúde Pública. 2014; 30(Sup):182-91.

11. Lansky S, Friche AAL, Silva AAM, Campos D, Bittencourt SDA, Carvalho ML, et al. Birth in Brazil survey: neonatal mortality profile, and maternal and child care. Cad Saúde Pública. 2014; 30(Sup):192-207.

12. Ministério da Saúde (BR). Secretaria de Atenção à Saúde. Departamento de Ações Programáticas Estratégicas. Gestação de Alto Risco. Manual Técnico. Brasília: Ministério da Saúde; 2012.

13. Gravena AAF, Paula MG, Marcon SS, Carvalho MDB, Pelloso SM. Maternal age and factors associated with perinatal outcomes. Acta Paul Enferm. 2013; 26(2):130-5.

14. Costa EL, Sena MCF, Dias A. Gravidez na adolescência - determinante para prematuridade e baixo peso. Comum Ciênc Saúde. 2011; 22(Sup1):183-8.

15. Victora CG, Aquino EML, Leal MC, Monteiro CA, Barros FC, Szwacwald CL. Saúde de mães e crianças no Brasil: progressos e desafios. Lancet [Internet]. 2011 [citado 2016 Abr 13]; 2:32-46. Disponível em: http://www.abc.org.br/IMG/pdf/ doc-574.pdf
16. Lages CDR, Sousa JCO, Cunha KJB, Silva NC, Santos TMMG. Predictive factors for the admission of a newborn in an intensive care unit. Rev Rene. 2014; 15(1):3-11.

17. Baños, LGG. Factores de riesgo asociados al bajo peso al nascer. Rev Cubana Salud Pública. 2012; 38(2):238-45.

18. Costa BC, Vecchi AA, Granzotto JA, Lorea CF, Mota DM, Albernaz EP, et al. Análise comparativa de complicações do recém-nascido prematuro tardio em relação ao recém-nascido a termo. Bol Cient Pediatr. 2015; 4(2):33-7.

19. Ministério da Saúde (BR). Secretaria de Atenção à Saúde. Departamento de Ações Programáticas e Estratégicas. Atenção à saúde do recém-nascido: guia para os profissionais de saúde. Brasília: Ministério da Saúde; 2011.

20. Duarte ED, Sena RR, Dittz ES, Tavares TS, Silva PM, Walty CMRF. Comprehensiveness of the care for the neonate: the articulation of management, training and care. Esc Anna Nery. 2013; 17(4):7132. 